\title{
Simultaneous Bilateral Spontaneous
Pneumothorax with CoVID-19 Pneumonia
}

\section{COVID-19 Pnömonisi ile Birlikte Simultane Bilateral Spontan Pnömotoraks}

Pelin Erdizci, Mustafa Akyıl, Serkan Bayram, Ozan Kaya, Serdar Evman, Volkan Baysungur

\begin{abstract}
The declared COVID-19 pandemic has come to affect the entire world. Ever since the first cases were detected, pneumothorax has been considered a rare but possible complication, and may develop in patients under mechanical ventilation due to high pressure. We present here a case of simultaneous bilateral spontaneous pneumothorax with COVID-19 pneumonia with no history of chronic lung disease and no mechanical ventilation.
\end{abstract}

Key words: Bilateral, COVID-19, pneumothorax, videothoracoscopy.

\section{Özet}

COVID-19, tüm dünyayı etkileyen bir salgın haline geldi. Illk olgular tespit edildiğinden beri, pnömotoraks nadir görülen bir olası komplikasyon olarak kabul edildi. Mekanik ventilasyon uygulanan hastalarda yüksek basınç nedeni ile pnömotoraks gelişebildiği bilinmektedir. Kronik akciğer hastalığı öyküsü olmayan ve mekanik ventilasyon uygulanmayan, COVID-19 pnömonisi ile birlikte simultane bilateral spontan pnömotoraks tespit ettiğimiz olgumuzu sunuyoruz.

Anahtar Sözcükler: Bilateral, COVID-19, pnömotoraks, videotorakoskopi.
Department of Thoracic Surgery, University of Health Sciences, Süreyyapasa Chest Diseases and Thoracic Surgery Training and Research Hospital, İstanbul, Turkey
Sağlık Bilimleri Üniversitesi Süreyapaşa Göğüs Hastalıkları ve Göğüs Cerrahisi Eğitim ve Araştırma Hastanesi, Göğüs Cerrahisi Kliniği, İstanbul

Submitted (Başvuru tarihi): 05.02.2021 Accepted (Kabul tarihi): 09.05.2021

Correspondence (iletişim): Pelin Erdizci, Department of Thoracic Surgery, University of Health Sciences, Süreyyapaşa Chest Diseases and Thoracic Surgery Training and Research Hospital, İstanbul, Turkey

e-mail: pelinerdizci@hotmail.com 
On March 11, 2020, the rapid increase in the number of patients worldwide led the World Health Organization (WHO) to declare COVID-19 a pandemic. COVID-19 infections can be asymptomatic or have mild symptoms, but can also cause severe symptoms, with fever, cough and shortness of breath being the most common $(1,2)$. Studies of the infection caused by SARS-CoV-2 have concluded that $1-2 \%$ of patients develop pneumothorax, having been reported as a rare possible complication since the initial COVID-19 outbreak $(3,4)$. In Chen et al. (3), of the 99 cases with a confirmed diagnosis of COVID-19, only one patient developed pneumothorax, while Yang et al (4). identified a case with the same diagnosis in an autopsy series involving 92 cadavers.

Patients with COVID-19 infections and respiratory failure are often treated with positive pressure ventilation, and this can lead to the development of pneumothorax and worsen the progression of the existing condition. As massive pneumothorax is a life-threatening condition, it must be diagnosed and treated as a matter of urgency. Simultaneous bilateral spontaneous pneumothorax, while extremely rare, carries a high risk of mortality due to sudden lung collapse and tension pneumothorax, and so requires urgent treatment (5-7).

\section{CASE}

Simultaneous bilateral pneumothorax was detected on chest radiography of a 17 -year-old male patient who was admitted to our emergency department with a complaint of chest pain. The patient had a history of smoking one pack per day for 7 years, while there was no comorbidity history. This was the patient's first pneumothorax attack. A tube thoracostomy with a wet suction-control closeddrainage system was applied to the right and left hemithorax (Figures $1 \mathrm{la}$ and b). A thoracic computed tomography (CT) taken the next day revealed bilateral ground-glass density that was more prominent on the right (Figure 2). The patient was referred to the department of infectious diseases and clinical microbiology with suspected COVID-19 pneumonia. A combined nose and throat swab test was taken from the patient, and prior to a positive result, 5-day azithromycin + hydroxychloroquine treatment was initiated due to the patient's high fever in the evening and $\mathrm{CT}$ findings compatible with COVID-19 pneumonia. A control combined nose and throat swab test was taken on the 13th day of hospitalization of the patient, whose first PCR test result was positive. Upon the receipt of a negative PCR test result on the 15th day of hospitalization, planned videothoracic surgery was performed and subpleural blebs were detected in the right hemithorax resected with wedge resection and a pleural abrasion were performed. In a control examination two weeks after discharge, a left recurrent pneumothorax was detected and tube thoracostomy with a wet suction-control closed-drainage system was performed. A videothoracoscopic wedge resection and apical pleural abrasion was performed to the left hemithorax on the third day of hospitalization. The tube thoracostomy was terminated on the postoperative third day, and the patient was discharged on the fifth postoperative day.

\section{DISCUSSION}

Among the complications associated with severe coronavirus 2 (SARS-CoV-2), the most frequently mentioned are acute respiratory syndrome and respiratory failure. Pneumothorax, on the other hand, is a rare possible complication with a stated incidence of $1 \%$ in literature.

Pneumothorax related to COVID-19 infection is thought to be caused by degeneration in the lung parenchyma, resulting from long-term inflammatory damage and the resulting air leaks. The process would appear to resemble the formation of pneumothoraxes in SARS caused by another virus in the Coronaviridae family. The alveolar damage caused by SARS-CoV-2 can lead to the rupture of the alveoli, and thus air leakage into the pleural space. In addition to alveolar damage, the presence of enlarged pneumocytes, as multinucleated syncytial cells in the alveolar spaces, has also been demonstrated, and it has been reported that pneumocyte desquamation and hyaline membrane may also be seen. The mechanism is thought to involve the rupture of the alveolar wall due to the increased pressure difference between the alveoli and pulmonary interstitium as a result of the diffuse alveolar damage caused by SARS-CoV-2, although this has not been fully clarified $(7,8)$.

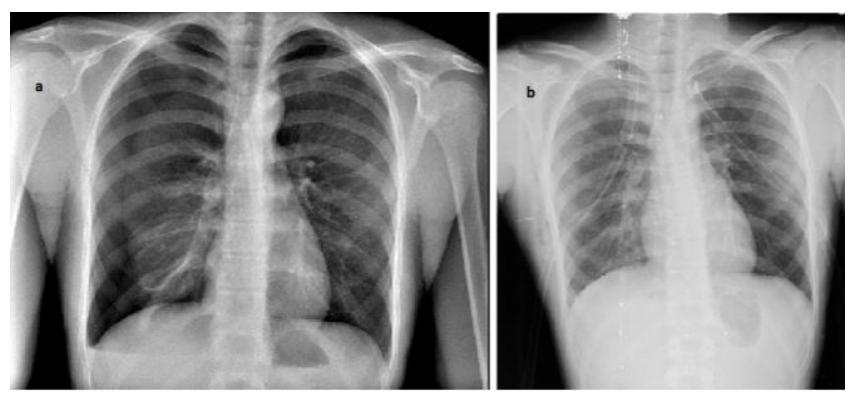

Figure la and b: Simultaneous bilateral pneumothorax detected in chest radiography of a 17-year-old male patient. Tube thoracostomy with a wet suction control closed-drainage system was applied to the right and left hemithorax, respectively 


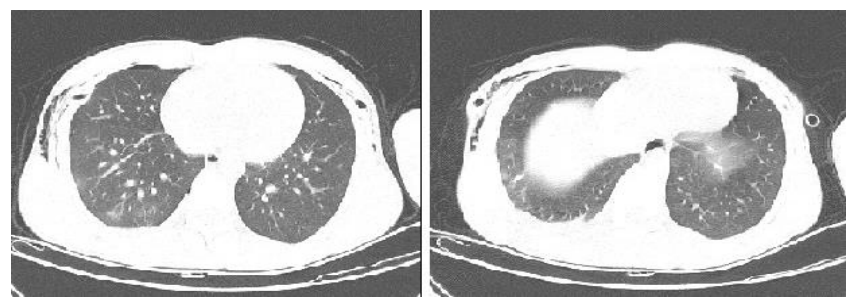

Figure 2: In the thoracic computed tomography (CT) taken the next day, a bilateral ground-glass density was detected that was more prominent on the right

The lung diseases that cause pneumothorax include cystic fibrosis, emphysema, necrotizing pneumonia, idiopathic pulmonary fibrosis, eosinophilic granulomatous disease, sarcoidosis, tuberculosis and lung cancer, although pneumothorax may also develop in patients who are mechanically ventilated due to the damage resulting from high pressure on the lung parenchyma (9). In some COVID-19 patients with pneumothorax, the presence of such underlying risk factors as chronic obstructive pulmonary disease (COPD) or the use of mechanical ventilation may raise doubts about the source of the complication pneumothorax being a known complication of intubationrelated mechanical ventilation $(6,10)$, but it seems that even without barotrauma, pneumothorax can coexist with COVID-19 $(10,11)$.

The case presented here was not treated with mechanical ventilation, and while there was a history of smoking, there was no COPD or other lung disease. We thus concluded that an alternative explanation should be sought for the development of pneumothorax in COVID-19 pneumonia. Tension pneumothorax is a possible complication, but most cases are reported as spontaneous pneumothorax $(12,13)$. Although tube thoracostomy provides satisfactory results in these patients, operative treatment should be considered as an option as longterm hospitalization may be required. The surgical approach to pneumothorax in COVID-19 patients has been determined as thoracoscopic bullectomy/blebectomy and pleurodesis (14).

It should be kept in mind that in patients with suspected COVID-19, pneumothorax may worsen the prognosis by causing acute respiratory decompensation. COVID-19 patients treated with mechanical ventilation are at risk of pneumothorax associated with ventilation, and so should be kept under constant observation (15). The management of pneumothoraxes in COVID-19 patients is vital for the prevention of life-threatening tension pneumothoraxes. Simultaneous bilateral primary spontaneous pneumothorax is rare, occurring in less than $2 \%$ of all pneumotho- raxes, and given the high risk of mortality, it should be treated as a matter of urgency $(16,17)$.

Chronic obstructive pulmonary diseases (COPDs) are reported to be the most common pathological factor in the development of concurrent bilateral secondary pneumothorax, and simultaneous bilateral pneumothorax can be seen after cystic fibrosis, malignancy metastasis, tuberculosis, trauma or interventions. The absence of any of these conditions in the case presented here raises the suspicion that COVID-19 was a factor in the development of simultaneous bilateral spontaneous pneumothorax. $(7,16,17)$.

\section{CONCLUSION}

Simultaneous bilateral spontaneous pneumothorax is an extremely rare but life-threatening condition that requires immediate diagnosis and treatment. Pneumothorax is a possible complication of COVID-19 pneumonia and should be considered in the differential diagnosis of COVID-19 patients who experience sudden respiratory decompensation.

\section{CONFLICTS OF INTEREST}

None declared.

\section{AUTHOR CONTRIBUTIONS}

Concept - P.E., M.A., S.B., O.K., S.E., V.B.; Planning and Design - P.E., M.A., S.B., O.K., S.E., V.B.; Supervision P.E., M.A., S.B., O.K., S.E., V.B.; Funding - R P.E., V.B., S.E.; Materials - V.B., S.E.; Data Collection and/or Processing - P.E., O.K., S.B.; Analysis and/or Interpretation P.E., M.A.; Literature Review - P.E., O.K.; Writing - P.E., O.K., M.A.; Critical Review - V.B., S.E., S.B.

\section{YAZAR KATKILARI}

Fikir - P.E., M.A., S.B., O.K., S.E., V.B.; Tasarım ve Dizayn - P.E., M.A., S.B., O.K., S.E., V.B.; Denetleme - P.E., M.A., S.B., O.K., S.E., V.B.; Kaynaklar - P.E., V.B., S.E.; Malzemeler - V.B., S.E.; Veri Toplama ve/veya İşleme P.E., O.K., S.B.; Analiz ve/veya Yorum - P.E., M.A.; Literatür Taraması - P.E., O.K.; Yazıyı Yazan - P.E., O.K., M.A.; Eleştirel İnceleme - V.B., S.E., S.B.

\section{REFERENCES}

1. Wang D, Hu B, Hu C, Zhu F, Liu X, Zhang J, et al. Clinical characteristics of 138 hospitalized patients with 2019 novel coronavirus-infected pneumonia in Wuhan, China. JAMA 2020; 323:1061-9. [CrossRef] 
2. Berlin DA, Gulick RM, Martinez FJ. Severe Covid-19. N Engl J Med 2020; 383:2451-60. [CrossRef]

3. Chen N, Zhou M, Dong X, Qu J, Gong F, et al. Epidemiological and clinical characteristics of 99 cases of 2019 novel coronavirus pneumonia in Wuhan, China: a descriptive study. Lancet 2020; 395:507-13. [CrossRef]

4. Yang $X, Y \cup Y, X \cup J$, Shu $H$, Xia J, Liu $H$, et al. Clinical course and outcomes of critically ill patients with SARSCoV-2 pneumonia in Wuhan, China: a single-centered, retrospective, observational study. Lancet Respir Med 2020; 8: 475-81. [CrossRef]

5. Jacobi A, Chung $M$, Bernheim A, Eber C. Portable chest $X$-ray in coronavirus disease-19 (COVID-19): a pictorial review. Clin Imaging 2020; 64: 35-42. [CrossRef]

6. Yang F, Shi S, Zhu J, Shi J, Dai K, Chen X. Analysis of 92 deceased patients with Covid-19. J Med Virol 2020; 92:2511-5. [CrossRef]

7. Williams-Johnson J, Williams EW, Hart N, Maycock C, Bullock K, Ramphal P. Simultaneous spontaneous bilateral pneumothoraces in an asthmatic. West Indian Med J 2008; 57: 508-10.

8. López Vega JM, Parra Gordo ML, Diez Tascón A, Ossaba Vélez S. Pneumomediastinum and spontaneous pneumothorax as an extrapulmonary complication of COVID-19 disease. Emerg Radiol 2020; 27:727-30. [CrossRef]

9. McCool FD. Diseases of the diaphragm, chest wall, pleura and mediastinum. In: Goldman L, Schafer Al, eds. Goldman- Cecil medicine. 26th ed. Philadelphia: Elsevier; 2020. p.602-12.

10. Yao W, Wang $T$, Jiang B, Gao F, Wang $L$, Zheng $H$, et al. Emergency tracheal intubation in 202 patients with
COVID-19 in Wuhan, China: lessons learnt and international expert recommendations. Br J Anaesth 2020; 125 : e28-e37. [CrossRef]

11. Zhou C, Gao C, Xie Y, Xu M. COVID-19 with spontaneous pneumomediastinum. Lancet Infect Dis 2020; 20 : 510. [CrossRef]

12. Spiro JE, Sisovic S, Ockert B, Böcker W, Siebenbürger G. Secondary tension pneumothorax in a COVID-19 pneumonia patient: a case report. Infection 2020; 48:941-4. [CrossRef]

13. Flower L, Carter JL, Rosales Lopez J, Henry AM. Tension pneumothorax in a patient with COVID-19. BMJ Case Rep 2020; 13: e235861. [CrossRef]

14. Aiolfi A, Biraghi T, Montisci A, Bonitta G, Micheletto $G$, Donatelli $F$, et al. Management of persistent pneumothorax with thoracoscopy and blebs resection in Covid-19 patients. Ann Thorac Surg 2020; 110:e413-e415. [CrossRef]

15. Quincho-Lopez A, Quincho-Lopez DL, Hurtado-Medina FD. Case Report: Pneumothorax and pneumomediastinum as uncommon complications of COVID-19 pneumonia-Literature review. Am J Trop Med Hyg 2020; 103:1 170-6. [CrossRef]

16. Lee SC, Cheng YL, Huang CW, Tzao C, Hsu HH, Chang $\mathrm{H}$. Simultaneous bilateral primary spontaneous pneumothorax. Respirology 2008; 13:145-8. [CrossRef]

17. Sayar A, Turna A, Metin M, Küçükyağci N, Solak $O$, Gürses $A$. Simultaneous bilateral spontaneous pneumothorax report of 12 cases and review of the literature. Acta Chir Belg 2004; 104: 572-6. [CrossRef] 